\title{
Stoichiometric and steric principles governing repression by nuclear hormone receptors
}

\author{
Iris Zamir, ${ }^{1,2}$ Jinsong Zhang, ${ }^{1,3}$ and Mitchell A. Lazar ${ }^{1,2,4}$ \\ Division of Endocrinology, Diabetes, and Metabolism, Departments of ${ }^{1}$ Medicine, ${ }^{2}$ Genetics, and ${ }^{3}$ Biochemistry, University \\ of Pennsylvania School of Medicine, Philadelphia, Pennsylvania 19104 USA
}

\begin{abstract}
We have defined two principles of corepressor function that account for differences in transcriptional repression by nuclear hormone receptors (NHRs). First, we have determined that receptor stoichiometry is a crucial determinant of transcriptional repression mediated by the corepressors N-CoR and SMRT. This provides a molecular explanation for the observation that NHRs repress transcription as dimers but not monomers. Second, corepressor function is restricted by steric effects related to DNA binding in a receptor-specific manner. Thus, although N-CoR and SMRT are capable of binding to several NHRs in solution, they are highly selective about receptor binding on DNA, a context that reflects their in vivo function more accurately. These stoichiometric and steric principles govern specific interactions between corepressors and NHRs, thus providing evidence that N-CoR and SMRT do not serve redundant functions but rather contribute to receptor-specific transcriptional repression.
\end{abstract}

[Key Words: Corepressor function; transcriptional repression; NHRs; stoichiometry; steric effects; nuclear hormone receptor; orphan receptor; PPAR; thyroid hormone receptor]

Received November 4, 1996; revised version accepted March 4, 1997.

Nuclear hormone receptors (NHRs) regulate cellular growth and differentiation and organ development by modulating gene transcription. In addition to ligand-dependent gene activation, selected NHRs including thyroid hormone receptor (TR) and retinoic acid receptor (RAR) repress basal transcription in the absence of ligand (Brent et al. 1989; Graupner et al. 1989; Baniahmad et al. 1992; Fondell et al. 1993; Casanova et al. 1994). The overall level of transcription of a specific gene is determined by the integration of positive and negative effects exerted by transcription factors on the basal transcription apparatus. In this way, transcription of a gene may depend on the net influence of multiple ligands and diverse signal transduction pathways that act both directly and via intervening proteins termed coactivators or corepressors.

Nuclear receptor corepressor (N-CoR) (Horlein et al. 1995) and SMRT (silencing mediator for retinoid and thyroid hormone receptor) ( $\overline{C h}$ en and Evañs 1995) are considered corepressor proteins because they interact with unliganded NHRs and function as adaptors to convey a repressive signal to the transcription apparatus. Ligand binding to the NHR leads to a conformational change in the receptor that results in dissociation of the corepressor. These events permit the NHR to bind dis-

${ }^{4}$ Corresponding author.

E-MAIL lazar@mail.med.upenn.edu; FAX (215) 898-5408. tinct adaptor proteins known as coactivators, which are involved in transactivation, such as SRC-1 (Onate et al. 1995), RIP-140 (Cavailles et al. 1995), Tripl (Lee et al. 1995), TIF-1 (LeDouarin et al. 1995), ERAPs (Halachmi et al. 1994), or CBP (Chakravarti et al. 1996; Hanstein et al. 1996; Kamei et al. 1996). An amphipathic $\alpha$-helix termed AF2 is present in the carboxyl terminus of many NHRs (Danielian et al. 1992) and serves to trigger the release of corepressor (Baniahmad et al. 1995; Chen and Evans 1995) and the recruitment of coactivator in the presence of ligand (Danielian et al. 1992; Barettino et al. 1994; Durand et al. 1994). NHRs lacking this AF2 region function as constitutive repressors. Natural examples include v-erbA (Damm et al. 1989; Sap et al. 1989), the retroviral oncoprotein, which is a mutated TR (Sap et al. 1986), as well as the orphan receptor RevErb (Lazar et al. 1989; Miyajima et al. 1989), which may play a role in adipocyte and muscle differentiation (Chawla and Lazar 1993; Downes et al. 1995). RevErb has no known ligand and constitutively represses transcription when bound as a dimer to a specific subset of DR2 sites (Harding and Lazar 1995). The repressive activity of RevErb is mediated by $\mathrm{N}-\mathrm{CoR}$, although the $\mathrm{N}-\mathrm{CoR}$ interaction domain of RevErb differs from that of TR and RAR (Zamir et al. 1996). Thus, N-CoR provides a common downstream pathway for transcriptional regulation by nuclear hormone receptors with different repression domains.

N-CoR and SMRT are related both structurally and functionally. Each contains at least two domains essen- 
tial for its function: an amino-terminal repression domain and a carboxy-terminal receptor-interaction domain. The amino terminus of N-CoR is considerably longer than that of SMRT and appears to contain three regions that contribute to repression, the most carboxyterminal of which is highly homologous to the SMRT repression domain. The receptor-interaction domains of $\mathrm{N}-\mathrm{CoR}$ and SMRT are even more highly related, being of similar size and containing multiple regions of significant homology that are essential for NHR interaction (Chen and Evans 1995; Horlein et al. 1995; Sande and Privalsky 1996; Zamir et al. 1996). Both N-CoR and SMRT have been shown to interact in solution with TR and $R A R$, and weakly with retinoid $X$ receptor (RXR), in the absence of the appropriate ligand. These similarities would suggest redundancy in the function of these corepressors, which is supported by the observation that mutations in the $\mathrm{D}$ domain CoR box of TR prevent interactions with both N-CoR and SMRT (Chen and Evans 1995; Horlein et al. 1995).

We have found that $\mathrm{N}$-CoR and SMRT both interact with a number of NHRs in solution. On DNA, binding to either corepressor requires contributions from two receptor carboxyl termini, such that only receptor dimers bind corepressor in this context. Furthermore, corepressor binding on DNA is restricted to specific corepressor and NHR combinations. Thus, TR interacts with both $\mathrm{N}-\mathrm{CoR}$ and SMRT on DNA, whereas RevErb interacts with N-CoR but not SMRT on DNA. Consistent with this finding, only N-CoR potentiates RevErb repression in transient transfection transcription assays. Finally, the adipogenic nuclear receptor peroxisome proliferatoractivated receptor $\gamma(\operatorname{PPAR} \gamma)$ interacts strongly with $\mathrm{N}$ CoR and SMRT in solution but not on the acyl coenzyme A (CoA) oxidase PPAR response element (PPRE), providing a molecular explanation for the observation that PPAR $\gamma$ does not repress transcription directly on this site. Selectivity of corepressor interactions with NHRs ensures that each corepressor will have specific, nonredundant cellular functions that may be regulated by distinct mechanisms.

\section{Results}

Transcriptional repression correlates with corepressor binding on DNA

The orphan nuclear receptor RevErb can bind to DNA as both a monomer and as a dimer (Harding and Lazar 1995). In Figure 1A we confirm that RevErb constitutively represses transcription from a reporter containing the RevDR2, to which it binds cooperatively as a homodimer. However, despite its ability to bind with high affinity to a Rev monomer site in vitro, RevErb was transcriptionally inactive on this site.

Because N-CoR has been implicated recently as a corepressor involved in RevErb function (Zamir et al. 1996), we investigated whether N-CoR could bind to RevErb on these sites. In Figure 1B, in vitro-translated RevErb bound to a RevDR2 as both a monomer and as a
A

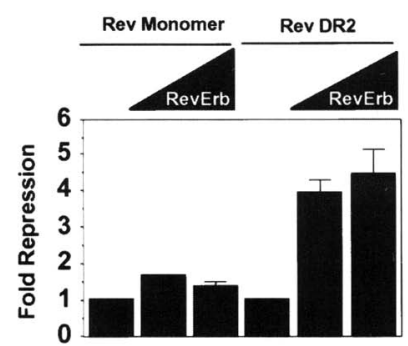

B

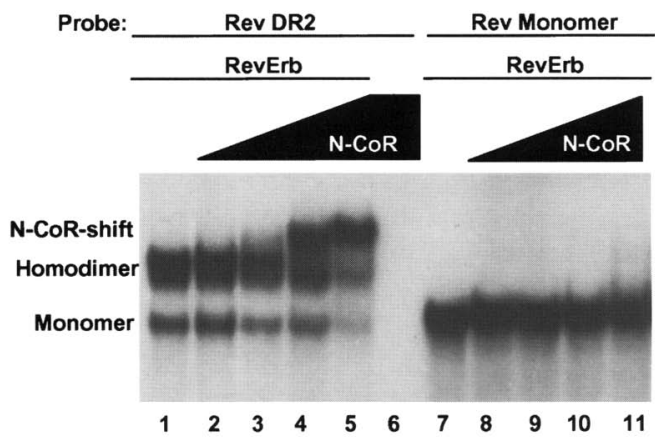

Figure 1. Correlation between transcriptional repression and dimeric DNA binding. $(A)$ RevErb represses transcription from a RevDR2 but not a Rev monomer site. 293T cells were transfected with increasing concentrations of RevErb expression plasmid $(0,0.25,3 \mu \mathrm{g})$ along with SV40-luciferase reporters containing either a single RevErb monomer site (Rev monomer) or a RevDR2 site. Results were normalized to $\beta$-galactosidase activity and expressed as fold repression relative to that in the absence of RevErb. (B) EMSA of RevErb binding to RevDR2 and monomer sites in the absence or presence of increasing concentrations of GST-N-CoR $(0,1,5,15,30 \mu \mathrm{g})$. Lane 6 contains mock-translated reticulocyte lysate.

cooperative dimer as described previously (lane 1; Harding and Lazar 1995). Addition of increasing concentrations of bacterially expressed N-CoR receptor-interaction domain [amino acids 1944-2239 [Zamir et al. 1996)] resulted in a shift of the RevErb - DNA complex (lanes $2-5$ |, indicating that $\mathrm{N}-\mathrm{CoR}$ can bind to the receptor on the RevDR2 site. In contrast, even high concentrations of N-CoR were unable to shift RevErb bound to the monomer probe (Fig. 1B, lanes 8-11), consistent with the inability of RevErb to function as a repressor on this site.

Two ligand-binding domains are required for $N$-CoR $\cdot$ RevErb interaction on DNA

Two hypotheses may explain the lack of N-CoR binding to RevErb on the monomer site. It is possible that a conformational change in one molecule of RevErb caused by cooperative homodimerization on the DR2 site is required for the $\mathrm{N}-\mathrm{CoR}$ interaction. Alternatively, two RevErb carboxyl termini, each containing the N-CoR interaction surface (Zamir et al. 1996), may be essential for $\mathrm{N}-\mathrm{CoR}$ binding. 
To test the first hypothesis, we studied the binding of $\mathrm{N}$-CoR to RevErb on a DNA site containing two widely spaced (20 bp) monomer sites, oriented as everted repeats (Monomer $\times 2$ ). In Figure 2A, RevErb bound to this site as a monomer and a homodimer. Homodimer binding is noncooperative on this binding site and most likely represents simply two RevErb molecules binding simultaneously to one molecule of probe (Harding and Lazar 1995). Lanes $8-10$ show that N-CoR selectively shifted the complex containing two RevErb molecules. This ability of two RevErb monomers to bind N-CoR on the monomer $\times 2$ binding site was of functional significance, as this binding site was capable of supporting transcriptional repression by RevErb as shown in Figure 2B. Thus, the presence of two RevErb molecules bound to DNA is sufficient for transcriptional repression and N-CoR binding, and this is independent of any conformational change mediated by cooperative binding on the RevDR2.

To determine whether two receptor carboxyl termini are required for $\mathrm{N}$-CoR binding, a mixing experiment was performed to generate a RevErb heterodimer containing only one RevErb carboxyl terminus. Figure $2 \mathrm{C}$ shows that when mixed with full-length RevErb (FL), the DNA-binding domain (DBD) heterodimerized with the full-length receptor resulting in a band that migrated slightly slower than the full-length RevErb monomer (lane 3, FL-DBD). Only the complex containing two RevErb carboxyl termini (FL-FL) was shifted by N-CoR, whereas the heterodimer containing only one Rev carboxyl terminus (FL-DBD) did not bind to N-CoR (cf. lanes 6 and 91. These results show conclusively that two carboxyl termini are necessary and sufficient for N-CoR binding to RevErb on DNA.

\section{Corepressors bind to $T R$ homodimers but not $T R$ monomers on DNA}

Because both SMRT and N-CoR have been shown to function as corepressors for TR (Chen and Evans 1995; Horlein et al. 1995), we extended our experiments to examine the stoichiometry of the TR interaction with each of these corepressors. The carboxyl terminus of SMRT (amino acids 982-1495) was fused to glutathione $S$-transferase (GST) for these studies, as this region has been shown to be sufficient to block receptor-interaction in vivo (Chen et al. 1996; Schulman et al. 1996) and sufficient for binding to both TR and RevErb in vitro (see Fig. 4A, below). TR subtypes differ in their abilities to interact with DNA as monomers and homodimers (Lazar 1993). TR $\alpha$ does not form cooperative homodimers (Lazar and Berrodin 1990; Darling et al. 1993) but has the ability to bind to monomeric sites (Lazar et al. 1991; Katz and Koenig 1993) from which it can activate transcription in the presence of ligand (Katz and Koenig 1994). Figure 3 confirms that TR $\alpha 1$ bound to a single half site as a monomer, but the monomeric TR did not interact with either N-CoR or SMRT on DNA. Similarly, TR $\alpha 1$ bound as a monomer to a DR4 response element but this form of TR did not interact with corepressors on DNA. On the same DR4 probe, TR $\beta 1$ formed stable, cooperative homodimers. In contrast to the TR $\alpha$ monomer, the TR $\beta$ homodimer complex was shifted by both N-CoR and
A

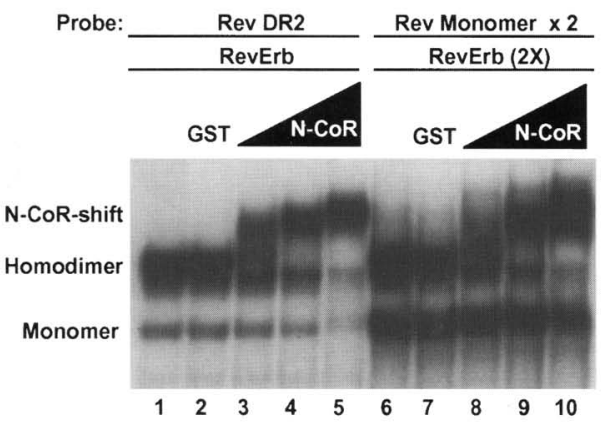

B

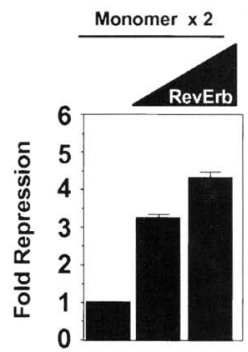

C

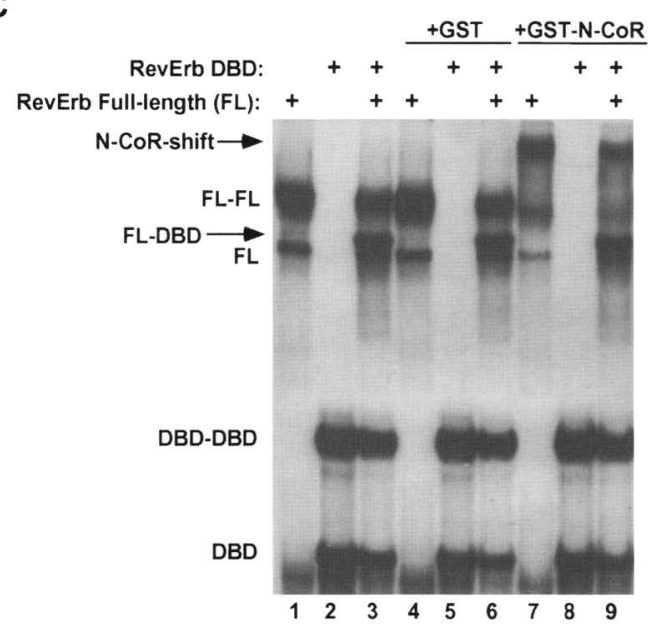

Figure 2. N-CoR binding to RevErb on DNA requires two RevErb molecules, each containing a corepressor interaction domain. (A) Two RevErb molecules are required for corepressor binding on the monomer $\times 2$ site (two RevErb monomer sites separated by 20 bp and oriented as everted repeats). EMSA of RevErb binding to RevDR2 and Rev monomer $\times 2$ sites in the absence or presence of GST alone $(30 \mu \mathrm{g})$ or increasing concentrations of GST-N-CoR $(0,5,15,30 \mu \mathrm{g})$. Twice as much RevErb protein was used to generate equal binding of monomers and dimers on the monomer $\times 2$ site. $(B)$ RevErb represses transcription from the monomer $\times 2$ site. 293T cells were transfected with increasing concentrations of RevErb expression plasmid $(0,0.25,3 \mu \mathrm{g})$ along with SV40-luciferase reporters containing the monomer $\times 2$ site. Results were normalized to $\beta$-galactosidase activity and expressed as fold repression relative to that in the absence of RevErb. (C) Two RevErb carboxyl termini are required for N-CoR binding on the RevDR2. EMSA of in vitro-translated full-length RevErb (FL) and the RevErb DBD (amino acids 103-225) binding to RevDR2 in the presence or absence of GST or GST-N-CoR. 


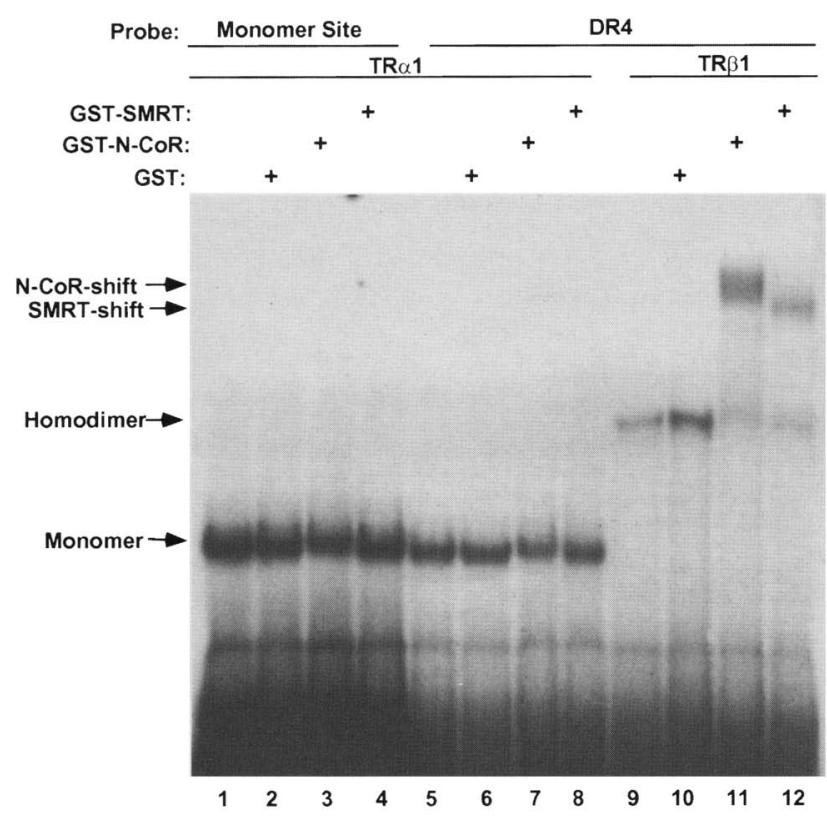

Figure 3. N-CoR and SMRT interact with TR homodimers but not TR monomers. EMSA with TR $\alpha 1$ or TR $\beta 1$, using a TR monomer site or DR4 element, in the presence or absence of GST, GST-N-CoR(1744-2453), or GST-SMRT.

SMRT, indicating that the corepressors interacted with TR homodimers but not with monomers. This was not because of a TR subtype-specific difference in corepressor interaction, as both $\operatorname{TR} \alpha$ and $\operatorname{TR} \beta$ bound corepressor in solution and on DNA as an RXR heterodimer (see below; Fig. 4; Chen and Evans 1995). Thus, TR is similar to RevErb in that two receptors are required to bind to corepressor on DNA.

\section{Corepressors bind to $T R \cdot R X R$ heterodimers in solution and on DNA}

The ability of RXR to interact with corepressors is somewhat controversial. There is evidence that RXR interacts weakly in solution with both $\mathrm{N}-\mathrm{CoR}$ and SMRT in a manner that is detectable in some assays but not in others (Chen and Evans 1995; Horlein et al. 1995; Sande and Privalsky 1996; Seol et al. 1996). We were interested in whether RXR could provide the second carboxy-terminal interaction domain necessary for corepressor complex formation either in solution or on DNA. In Figure 4A, GST fusion proteins containing either the N-CoR or SMRT receptor-interaction domains were able to pull down ${ }^{35} S$-labeled in vitro-translated $T R \alpha 1, T R \beta 1$, or RevErb but not RXR $\alpha$ (lanes 7, 14). Thus, the putative weak interactions between RXR and N-CoR or SMRT were not detected in this assay. In contrast, $\operatorname{RXR} \alpha$ was pulled down as part of the receptor-corepressor complex in the presence of either TR $\alpha 1$ or TR $\beta 1$ (cf. lane 7 with lanes 9 and 10 and lane 14 with lanes 16 and 17; unlabeled TR $\beta 1$ was used to avoid confusion, as TR $\beta 1$ and RXR $\alpha$ migrate similarly on SDS-PAGE). Thus, although we did not detect RXR binding to corepressor in the absence of TR, RXR did interact with both N-CoR and SMRT in the form of a heterodimer with TR. RevErb, which does not heterodimerize with RXR (Harding and
Figure 4. N-CoR and SMRT interact with TR · RXR heterodimers. (A) Solution assay. $\operatorname{TR} \alpha, \operatorname{TR} \beta, \operatorname{RXR} \alpha$, and RevErb were ${ }^{35} \mathrm{~S}$-labeled in reticulocyte lysate and incubated with GST-N-CoR, GST-SMRT, or GST alone as indicated prior to washing and SDS-PAGE. TR $\alpha$, TR $\beta$, and RevErb were also mixed with $\operatorname{RXR} \alpha$ as indicated. When TR $\beta$ and RXR $\alpha$ were mixed, unlabeled TR $\beta$ was used (lanes 10,17 ) to avoid potential confusion between labeled $\operatorname{TR} \beta$ and $\operatorname{RXR} \alpha$, which migrate similarly (cf. lanes 2 and 3). (B) EMSA analysis. TR $\alpha$ or TR $\beta$ were mixed with $\operatorname{RXR} \alpha$, and GST-N-CoR, anti-RXR $\alpha$ antibody, or both. EMSA was performed with DR4 probe (runoff gel).
A

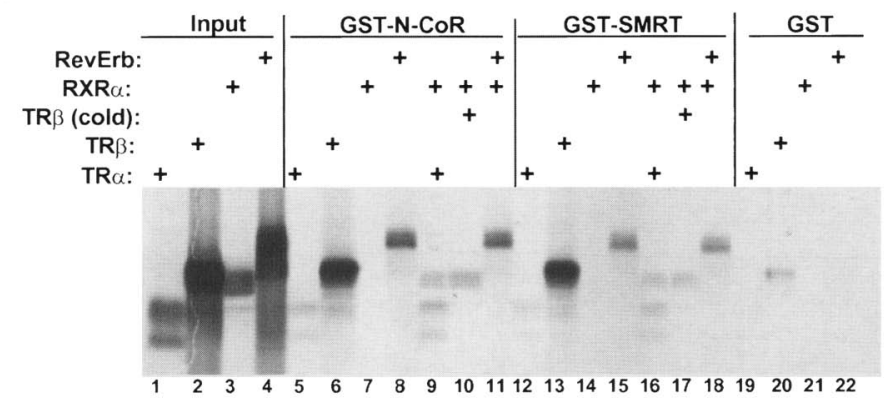

B

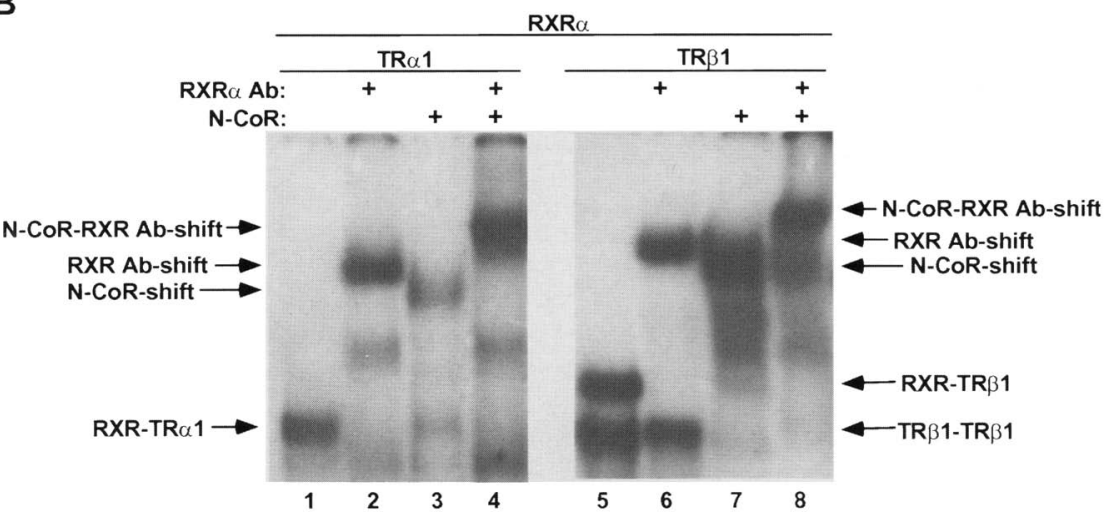


Lazar 1993), did not pull down RXR in its complex with N-CoR (lane 11). RevErb also interacted with GSTSMRT (lane 15; see below) but again could not recruit RXR to this complex (lane 18).

Next we investigated whether corepressor could interact with TR - RXR bound to DNA. Figure 4B shows that TR $\alpha 1 \cdot$ RXR heterodimers bound cooperatively to a DR4 element (lane 1), and that anti-RXR antibody shifted the TR - RXR heterodimer bound to DNA (lane 2). Addition of N-CoR nearly eliminated the TR - RXR - DNA complex and resulted in a supershifted complex indicating that N-CoR was binding to TR $\alpha$ l on DNA (lane 3). The presence of RXR in the N-CoR-containing complexes was confirmed by supershift with anti-RXR antibody (cf. lane 4 with lanes 2 and 3). These results prove that an $\mathrm{N}-\mathrm{CoR} \cdot \mathrm{TR} \alpha \mathrm{l} \cdot \mathrm{RXR} \cdot \mathrm{DR} 4$ complex was formed. The specificity of the antibody for RXR was demonstrated by supershift of only TR $\beta 1 \cdot R X R$ heterodimers but not TR $\beta 1$ homodimers (cf. lanes 5 and 6). TR $\beta 1 \cdot R X R$ heterodimers similarly formed complexes with $\mathrm{N}-\mathrm{CoR}$ on DNA (lane 7), and the presence of RXR in these complexes was again confirmed by supershift with anti-RXR antibody (cf. lanes 7 and 8). Thus, TR - RXR heterodimers can bind N-CoR on DNA. Similar results were obtained with TR $\cdot$ RXR heterodimers and SMRT (data not shown), confirming the results of Evans and colleagues who have shown previously that SMRT can interact with the TR - RXR complex on DNA (Chen and Evans 1995; Schulman et al. 1996).

\section{SMRT and $\mathrm{N}$-CoR interact differentially with several RevErb polypeptides}

N-CoR and SMRT are highly homologous in their receptor-interaction domains, and they interact with similar if not identical $\mathrm{D}$ domain sequences in $\mathrm{TR}$ and $\mathrm{RAR}$ (Chen and Evans 1995; Horlein et al. 1995). Therefore, these corepressors have been deemed to perform redundant functions. We were interested in whether SMRT would interact with the RevErb repression domain. In Figure 4A, lane 15, full-length RevErb interacted with the NHR-interaction domain of SMRT in the absence of DNA. In Figure 5A we compared the ability of SMRT and N-CoR to interact with GST-RevErb, focusing on three regions indicated as shaded boxes in the schematic drawing of RevErb in Figure 5B. SMRT and N-CoR interacted differentially with this series of RevErb deletion mutants, and these results are summarized in Figure 5B. In the polypeptide labeled 200-614(407-18A), all 12 amino acids from 407 to 418 were mutated to alanines to avoid major structural disruption that might have resulted from an in-frame deletion of this region. Consistent with our previous observations, RevErb(376-614) was sufficient for $\mathrm{N}$-CoR binding, and amino acids 407418 and 602-614 are required for N-CoR to interact with this polypeptide (Zamir et al. 1996). Interestingly, Figure 5 also shows that RevErb(200-376) contributes to the RevErb $\cdot \mathrm{N}$-CoR interaction. Each of the three domains was incapable of interacting independently with N-CoR, but any RevErb carboxy-terminal polypeptide that contained at least two of these domains was able to bind N-CoR.

In contrast, interaction with SMRT absolutely required motifs located between amino acid 200 and 376 in RevErb, and this region was both necessary and sufficient for SMRT binding. Although this region of RevErb contains the CoR box, mutations analogous to those that abolish binding of corepressors to TR (Horlein et al. 1995) did not affect RevErb binding to SMRT (data not shown).

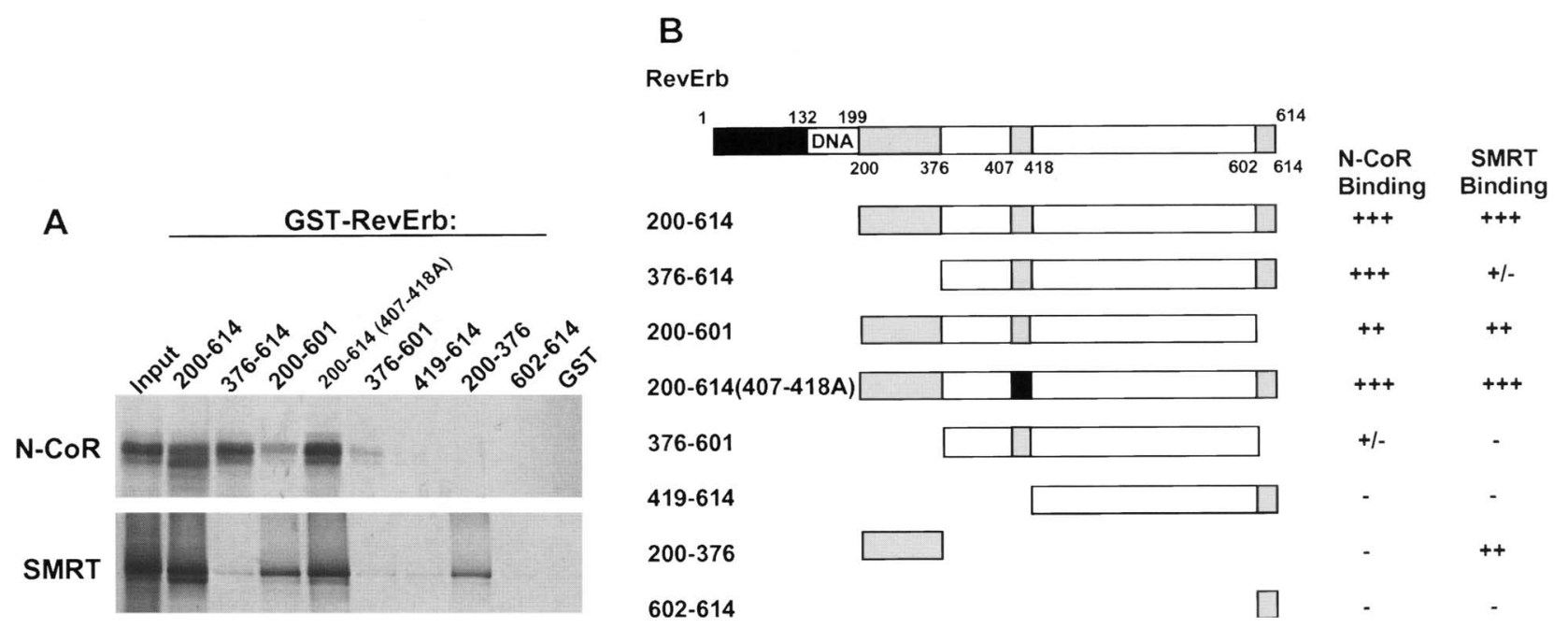

Figure 5. RevErb interacts with $\mathrm{N}$-CoR and SMRT using different interaction surfaces. $(A)$ Interaction of ${ }^{35} \mathrm{~S}$-labeled reticulocyte lysate translated N-CoR (1510-2453) and SMRT (full length) with indicated GST-RevErb proteins. (B) Summary of results in $A$. Regions that are the focus of the mutational analysis are shaded, except in the 200-614(407-418A) polypeptide, where the mutated region is shaded black. 
SMRT is not a corepressor for RevErb because it does not bind to RevErb on DNA

Because SMRT binds to RevErb in solution, we were interested in whether SMRT functions as a corepressor for RevErb, particularly because the N-CoR - RevErb interaction correlates directly with repression by RevErb in $293 \mathrm{~T}$ cells (Zamir et al. 1996). Using a transient transfection transcription assay, we compared the ability of $\mathrm{N}-\mathrm{CoR}$ and SMRT to potentiate RevErb repression. Repression by RevErb on a RevDR2 site upstream of a luciferase reporter was normalized to 1 , and the increase in repression because of increasing concentrations of corepressor was plotted as fold potentiation (Fig. 6A). N-CoR potentiated RevErb repression two- to threefold. Surprisingly, however, SMRT did not potentiate repression and, if anything, slightly decreased the ability of RevErb to repress transcription on this site. Addition of SMRT expression plasmid to the RevErb reporter in the absence of receptor had no effect on basal transcription (data not shown). This SMRT expression plasmid potentiated repression by TR $\beta 1$ to a similar extent as N-CoR (Fig. 6B), indicating that the plasmid expresses functional SMRT protein. Thus, despite the fact that SMRT can bind to RevErb in solution, it does not appear to be involved in repression by RevErb in 293T cells.

One possible explanation for the inability of SMRT to potentiate RevErb repression despite interacting with RevErb in solution was that it does not interact with RevErb on DNA. Therefore, we investigated whether the receptor-interacting domain of SMRT could bind to RevErb on DNA. Remarkably, under conditions in which N-CoR was able to shift RevErb on the RevDR2, SMRT had no such effect (Fig. $6 \mathrm{C}$ ). The same preparation of SMRT was able to shift TR on DNA, indicating that functional protein was used in this assay (see Fig. 7B, below). We conclude that SMRT is not a corepressor for RevErb on the molecular basis that SMRT does not bind to RevErb homodimers on a RevErb response element.

PPAR $\gamma$ binds N-COR and SMRT in solution but is not a transcriptional repressor because it cannot bind corepressors on DNA

In an effort to generalize these effects to other members of the nuclear receptor superfamily, we examined the interaction of $\mathrm{N}-\mathrm{CoR}$ and SMRT with PPAR $\gamma$, a receptor that binds DNA exclusively as a heterodimer with RXR. PPAR $\gamma$ is induced early in adipogenesis /Chawla et al. 1994; Tontonoz et al. 1994a) and is involved in the regulation of early events in adipocyte differentiation and in the transcriptional control of proteins involved in energy homeostasis (Tontonoz et al. 1994a,b; 1995). We were interested in the potential role of NHR corepressors in regulating these processes. In Figure 7A, PPAR $\gamma 1$ and PPAR $\gamma 2$ bound to both N-CoR and SMRT in vitro. The regions of N-CoR and SMRT that interacted with PPAR $\gamma$ in this assay corresponded to those that interacted most strongly with RevErb and TR (Zamir et al. 1996; data not shown|. However, Figure $7 \mathrm{~B}$ shows that these same regions of both corepressors were unable to interact with PPAR - RXR heterodimers on the acyl CoA oxidase PPRE (lanes 19-29). In the same experiment TR interacted with both N-CoR and SMRT (lanes 6,7) and RevErb selectively interacted with $\mathrm{N}$-CoR (lanes 13,14$)$, as shown earlier. Upon longer exposure of the autoradiograph shown in Figure 7D, binding of SMRT to PPAR $\gamma \cdot$ RXR
A

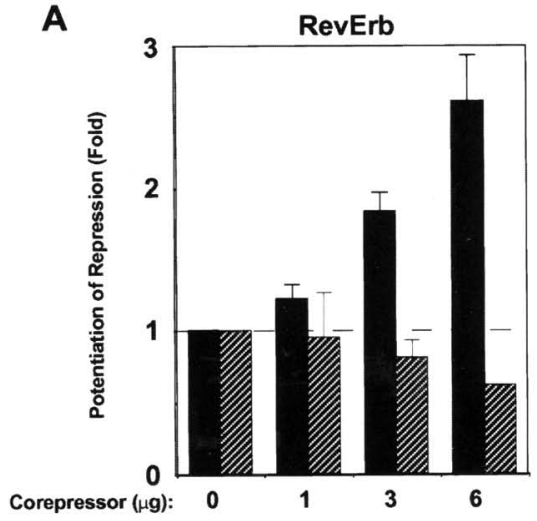

B

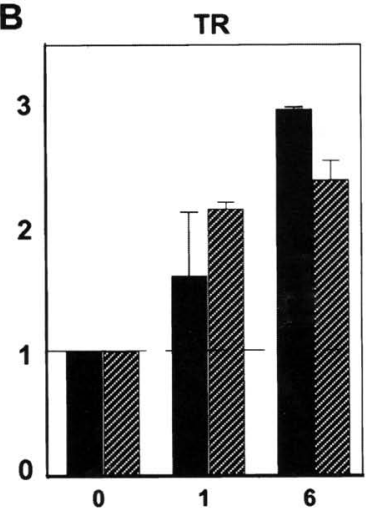

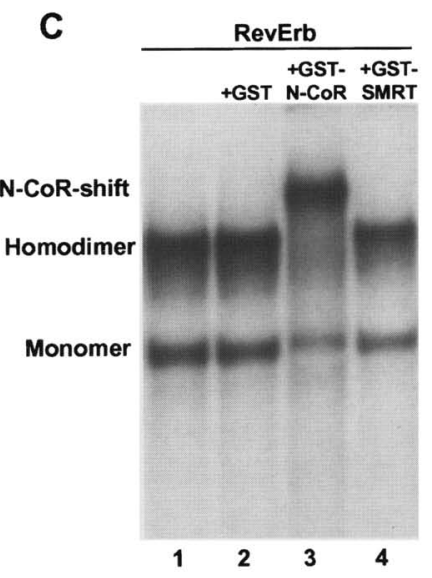

Figure 6. SMRT selectively binds nuclear receptors on DNA, correlating with its repressive function. (A) N-CoR but not SMRT potentiates RevErb repression. 293T cells were transfected with RevErb and increasing concentrations N-CoR (solid bars) or SMRT (hatched bars) expression plasmid along with SV40-luciferase reporters containing a single RevDR2 site. Results were normalized to $\beta$-galactosidase activity and expressed as fold potentiation of repression by RevErb alone. $(B)$ Both N-CoR and SMRT potentiate TR repression. 293T cells were transfected with Gal4-TR $\beta$ and increasing concentrations N-CoR (solid bars) or SMRT (hatched bars) expression plasmid along with an SV40-luciferase reporter containing five Gal4 binding sites. Gal4-TR $\beta 1$ was used for this experiment because the luciferase gene itself contains a negative thyroid hormone responsive element (Maia et al. 1996; Tillman et al. 1993). Results were normalized to $\beta$-galactosidase activity and expressed as fold potentiation of repression by TR alone. $(C)$ RevErb interacts with N-CoR but not SMRT on DNA. EMSA using RevDR2 probe along with RevErb mixed with GST, GST-N-CoR, or GST-SMRT. 
A

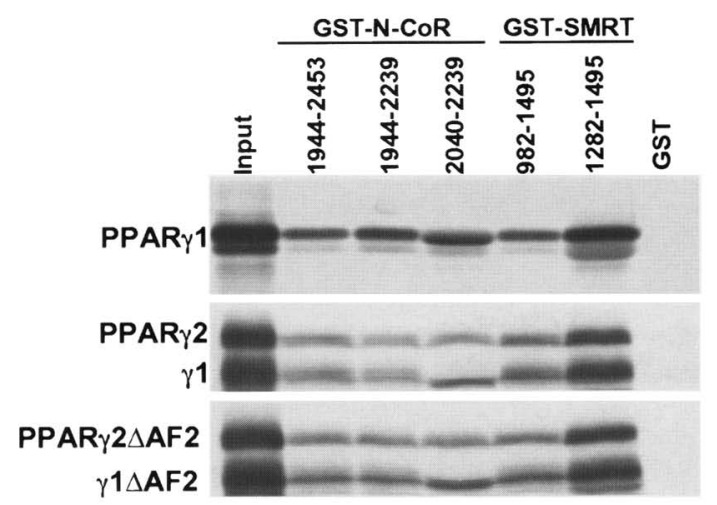

B

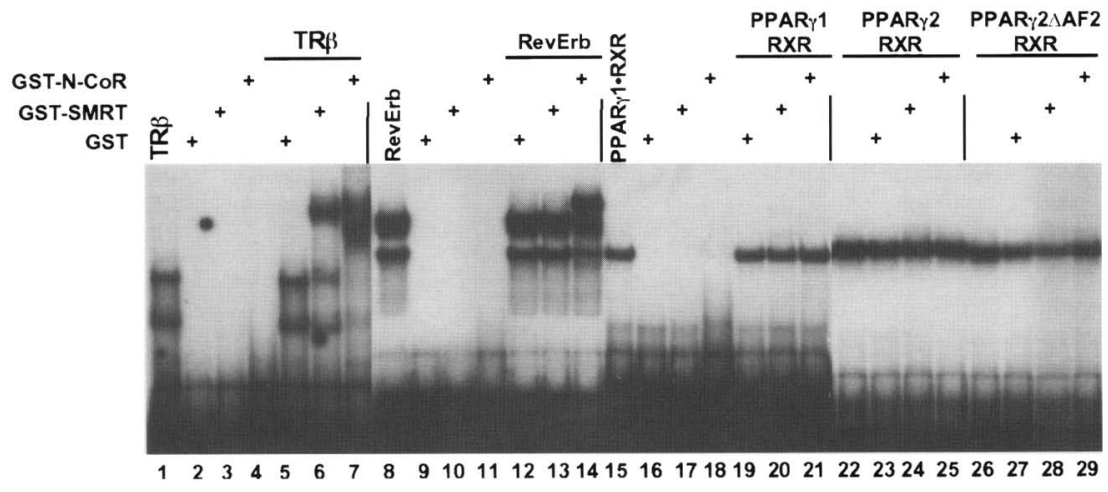

C

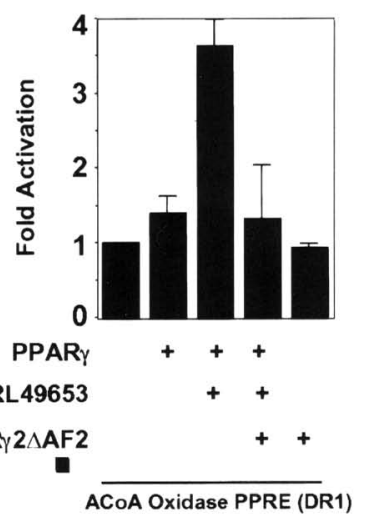

D

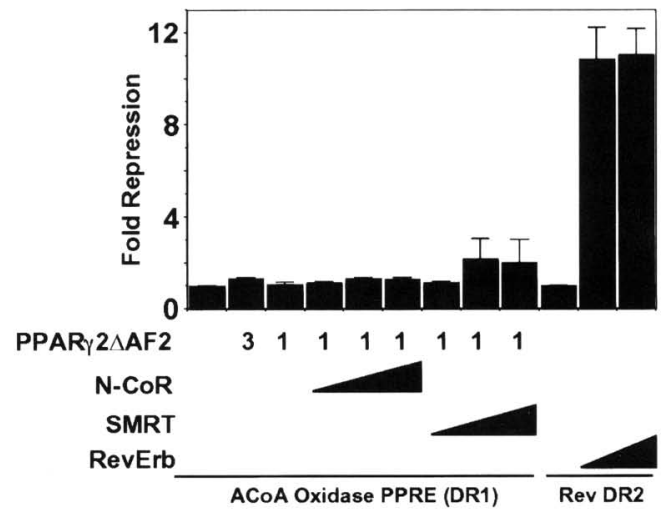

Figure 7. PPAR $\gamma$ interacts with N-CoR and SMRT in solution but not on DNA, and does not repress transcription. (A) PPAR $y 1$, PPAR $\gamma 2$, and PPAR $\gamma 2 \triangle A F 2$ interact with N-CoR and SMRT in solution. Interaction of ${ }^{35} \mathrm{~S}$-labeled reticulocyte lysate-translated PPAR $\gamma$ proteins with GST and the indicated GST-N-CoR and GSTSMRT fusion proteins. PPAR $\gamma 2 \mathrm{cDNA}$ is translated into both PPAR $\gamma 2$ and PPAR $\gamma 1$ (Tontonoz et al. 1994a; Xue et al. 1996). (B) PPAR $y$. RXR heterodimers do not interact with N-CoR or SMRT on DNA. EMSA of TR $\beta$ (with DR4 probe), RevErb (with RevDR2 probel, and PPAR $y 1 \cdot \mathrm{RXR}$, PPAR $2 \cdot$ RXR, and PPAR $\gamma 2 \Delta \mathrm{AF} 2 \cdot \mathrm{RXR}$ (with ACOA oxidase DR1 probe) in the presence or absence of GST, GST-N-CoR, and GST-SMRT. (C) PPAR $\gamma$ activates transcription, and PPAR $\gamma 2 \triangle \mathrm{AF} 2$ functions as a dominant inhibitor. $293 \mathrm{~T}$ cells were transfected with PPAR $\gamma 2$ and/or PPAR $\gamma 2 \triangle A F 2$ along with SV40-luciferase reporter containing the $\mathrm{ACOA}$ oxidase PPRE. Where indicated, cells were exposed to the PPAR $\gamma$-ligand BRL49653 (10 $\mu \mathrm{M})$. (D) PPAR $\gamma 2 \triangle \mathrm{AF} 2$ does not repress transcription from the acyl CoA oxidase PPRE. Where indicated, cells were also transfected with N-CoR or SMRT (1, 3, or $6 \mu \mathrm{g})$. In the same experiment, analysis of RevErb ( 1 and $3 \mu \mathrm{g}$ ) repression from the RevDR2 was performed. was detected (data not shown), but this interaction is unlikely to be functionally significant (see below).

Transfection of PPAR $y$ failed to repress transcription of a luciferase reporter gene containing the acyl CoA oxidase PPRE (Fig. 7C). PPAR $\gamma$ slightly increased transcription, presumably because of endogenous ligand present in the cells under these conditions (Keller et al. 1993; Yu et al. 1995). Addition of the ligand BRL49653 resulted in further activation of this reporter gene. The failure of PPAR $\gamma$ to repress transcription might have resulted from dissociation of corepressor by an endogenous ligand. To rule this out we created PPAR $\gamma 2 \Delta \mathrm{AF} 2$, an 11amino-acid carboxy-terminal deletion mutant that lacks the AF2 activation helix. Similar mutants of TR (v-erbA) and RAR (RAR $\alpha \Delta 403$ ) function as dominant negatives and retain the ability to interact with corepressors and thereby function as constitutive repressors /Chen et al. 1995). Like wild-type PPAR $\gamma, \operatorname{PPAR} \gamma 2 \Delta \mathrm{AF} 2$ interacted with GST-SMRT and GST-N-CoR in solution (Fig. 7A, bottom) and bound the PPRE as a heterodimer with RXR (Fig. 7B, lanes 26-29). As expected, because of its lack of AF2, PPAR $\gamma 2 \Delta \mathrm{AF} 2$ did not activate transcription in response to BRL49653 despite being expressed in transfected cells at levels similar to PPAR $\gamma 2$ (data not shown). PPAR $\gamma 2 \Delta$ AF2 functioned as a dominant-negative inhibitor of PPAR $y$ in vivo (Fig. 7C). Figure 7B shows that the PPAR $\gamma 2 \triangle \mathrm{AF} 2 \cdot \mathrm{RXR}$ heterodimer did not interact with N-CoR or SMRT on DNA (lanes 28,29 ). From this, we predict that PPAR $\gamma 2 \Delta \mathrm{AF} 2$ would not function as a constitutive repressor. Figure $7 \mathrm{D}$ shows that PPAR $\gamma 2 \Delta \mathrm{AF} 2$ 
did not repress basal transcription from the acyl CoA oxidase PPRE on its own or in the presence of cotransfected N-CoR or SMRT. In contrast, in the same experiment RevErb repressed transcription $>10$-fold from a reporter that was identical except that a single RevDR2 site replaced the PPRE and, as noted earlier, repression by RevErb was potentiated by N-CoR. Thus, the failure of PPAR $\gamma \cdot$ RXR to bind either N-CoR or SMRT on the acyl CoA oxidase PPRE correlates with the inability of $\operatorname{PPAR} \gamma$ to function as a repressor on this site in vivo.

\section{Discussion}

Stoichiometry of nuclear hormone receptor interactions with corepressors on DNA

We have shown that binding of N-CoR and SMRT to NHRs on DNA requires two receptor carboxyl termini. The interaction with corepressor is unlikely to be mediated by a conformational change caused by cooperative binding to DNA because RevErb bound noncooperatively to the monomer $\times 2$ site yet still bound corepressor and repressed transcription on this site (Fig. 2). Thus, the presence of two carboxyl termini is sufficient for interaction with corepressor. This may be attributable to conformational change in the receptor caused by interaction between the two carboxyl termini, or to direct binding of both receptor carboxyl termini by the corepressor complex. In addition, because RevErb and TR do not form stable homodimers in solution (Harding and Lazar 1995; Reginato et al. 1996), it is possible that the functional interactions between the corepressor and the two NHR carboxyl termini are facilitated by DNA binding. Whether the NHR dimers interact with one or multiple corepressor molecules remains to be determined.

The inability of corepressors to bind to receptor monomers on DNA explains why TR and RevErb do not repress transcription on monomer binding sites (Katz and Koenig 1994; Harding and Lazar 1995). Although RevErb does not actively repress basal transcription as a monomer, it can function as a competitive inhibitor of other NHRs that activate transcription from a monomeric site, such as ROR $\alpha 1$ (Forman et al. 1994; Retnakaran et al. 1994; Harding and Lazar 1995). In contrast, homodimers of TR and RevErb are potent repressors of transcription (Harding and Lazar 1995; Piedrafita et al. 1995; Adelmant et al. 1996).

The requirement of two carboxyl termini for corepressor binding has implications for the role of RXR in repression by NHRs. RXR binds corepressors very weakly, if at all, in vitro (Fig. 4; Kurokawa et al. 1995; Sande and Privalsky 1996; Seol et al. 1996), much less avidly than TR or RAR in yeast (Horlein et al. 1995; Kurokawa et al. 1995; Sande and Privalsky 1996; Seol et al. 1996), and does not repress transcription in vivo (Martin et al. 1994). In addition, TR monomers do not bind corepressors on DNA (Fig. 3). Nevertheless, TR · RXR can form complexes with corepressors in solution (Fig. 4A) and on DNA (Fig. 4B; Chen and Evans 1995; Schulman et al. 1996). Thus, heterodimerization with RXR provides the interaction surface necessary for corepressor recruitment on DNA. AF2 mutations in RXR prevent dissociation of corepressor from RAR - RXR heterodimers on DNA (Schulman et al. 1996). Similar mutations in RXR function as dominant-negative inhibitors of transcriptional activation by RAR (Minucci et al. 1994). This suggests that as we have shown for corepressors, physical interaction between coactivators and NHRs on DNA may require contributions from both NHRs in the dimer. It is tempting to speculate that this important function of receptor dimerization may be extended to other families of transcription factors that function as dimers.

\section{Regulation of corepressor interactions with nuclear hormone receptors by DNA binding}

We have shown that three domains in RevErb are involved in binding to $\mathrm{N}-\mathrm{CoR}$, any two of which are sufficient for stable interaction. The corepressor SMRT also interacts with RevErb in solution, but in contrast to NCoR, absolutely requires amino acids 200-376 in the RevErb hinge (Fig. 5). The obervation that RevErb interacts with N-CoR but not SMRT on DNA (Fig. 6) shows clearly that DNA binding plays an active and regulatory role in regulating the interaction between NHRs and corepressors. We suggest that a steric effect attributable to DNA binding blocks access of the corepressor to the interaction domain within RevErb(200-376), thereby preventing SMRT from binding on DNA. This steric effect does not prevent the N-CoR interaction because amino acids 376-614 of RevErb are sufficient for N-CoR binding.

TR is able to bind to N-CoR and SMRT on DNA and mediates transcriptional repression through both corepressors. Mutations in the TR CoR box eliminate these interactions (Chen and Evans 1995; Horlein et al. 1995) while analogous mutations in RevErb do not (Zamir et al. 1996; data not shown). This suggests that the SMRT interaction surfaces in TR and RevErb are distinct and may explain the differential binding of SMRT to these receptors on DNA. Alternatively, DNA may not affect corepressor binding to TR because of an inherent difference in either the TR DBD or the spacing of the response element (RevErb binds to a DR2 while TR binds to DR4).

PPAR $y$ binds to DRl sites as a heterodimer with RXR. Despite the fact that PPAR $\gamma$ binds to both N-CoR and SMRT in solution, the PPAR $\gamma \cdot \operatorname{RXR}$ heterodimer does not bind N-CoR on DNA and binds SMRT only weakly on the acyl CoA oxidase PPRE. We suggest that the necessary corepressor binding motifs in PPAR $\gamma$ are obscured by DNA binding. This may be attributable to the position of these motifs within PPAR $y$, the conformation of the DRl-binding site, or allosteric change caused by DNA binding of the PPAR $\gamma /$ RXR heterodimer. Alternatively, the corepressor-interaction domain of PPAR $\gamma$ may be insufficient to stably bind corepressor in combination with the relatively weak RXR corepressor-interaction domain. Regardless of the mechanism, the weak corepressor binding to PPAR $y$ on the acyl CoA oxidase PPRE correlates with the inability of both wild-type and 
AF2-deleted PPAR $\gamma$ to repress transcription on this site. The ability of PPAR $\gamma$ to interact with corepressor in solution raises the possibility that PPAR $\gamma$ could repress transcription on other sites or in other cell types, and this could be a specific function of SMRT that bound weakly to PPAR $y$ on the acyl CoA oxidase site. Furthermore, the potential role of corepressors in the activity of other isoforms of PPAR ( $\alpha$ and $\delta$ ), which have distinct structure, tissue distribution, ligands, and function (Kliewer et al. 1994; Yu et al. 1995; Devchand et al. 1996), remains to be determined.

\section{Implications for corepressor diversity}

We have shown that NHRs that interact with corepressors in solution differ in their abilities to interact with corepressors on DNA. Receptors such as TR bind both $\mathrm{N}-\mathrm{CoR}$ and SMRT on DNA and can utilize either corepressor to mediate repression. RevErb is an example of an NHR that distinguishes between N-CoR and SMRT by binding only to N-CoR on DNA and therefore mediates repression on its homodimeric binding site through $\mathrm{N}$-CoR alone. PPAR $\gamma$ defines a third class of NHR that can bind to both N-CoR and SMRT in solution but not to $\mathrm{N}$-CoR and only very weakly to SMRT on the naturally occurring PPRE from the acyl CoA oxidase gene. Thus, rather than serving redundant functions, the multiple corepressors allow for specificity of repression and raise the possibility that additional NHR corepressors with nonredundant functions exist. Regulation of the availability or activity of a specific corepressor may selectively affect repression mediated by distinct NHRs.

\section{Materials and Methods}

\section{Plasmid constructs for transfection}

Expression vectors for RevErb (Harding and Lazar 1993), N-CoR (Horlein et al. 1995), SMRT (Chen and Evans 1995), PPAR $\gamma 1$ (Kliewer et al. 1994), and PPAR 2 (Tontonoz et al. 1994a) have been described elsewhere. Gal4-TR $\beta 1$ was made by ligating the TR $\beta 1$ ligand-binding domain (amino acids 175-461) in-frame into a Gal4(1-147) expression vector. PPAR $\gamma 2 \triangle A F 2$, lacking the carboxy-terminal 11 amino acids of PPAR $\gamma$, was created using PPAR $\gamma 2$ as a PCR template with the primers 5'-cggtaccatggttgacacagagatgc- $3^{\prime}$ and $5^{\prime}$-cgtcgacctagtgaaggctcatgtctgtc- 3 ' and ligated into pCMX. Reporter vectors were generated by cloning oligonucleotides into the BglII site of the pTK luciferase reporter (Harding and Lazar 1995). The response elements are as follows (with hexameric half sites underlined): RevDR2, agatccaactaggtcactaggtcaaagggatct; Rev (monomer site), ggatccgactagatccagaatgtaggtcaggatct; $\operatorname{Rev}($ monomer $\times 2)$, agatcctgacctacattctggatccagaatgtaggtcaggtct; acyl CoA PPRE, gatctggaccagga caaaggtcacgttca (Dreyer et al. 1992); and five Gal 4-binding sites, described in Harding and Lazar (1993).

\section{Cell culture and transfection}

$293 \mathrm{~T}$ cells were maintained and transfected in Dulbecco's modified Eagle medium high glucose with $10 \%$ fetal calf serum. At $80 \%$ confluence, $60-\mathrm{mm}$ dishes were transfected by the calcium phosphate precipitation method using $1 \mu \mathrm{g}$ of luciferase reporter, $0.5 \mu \mathrm{g}$ of $\beta$-galactosidase ( $\beta$-gal) expression vector, and receptor or corepressor expression vector in quantities indicated in the figure legends. Empty expression vector (CDM or CMX) was added to equalize total transfected plasmid concentration. Cells were lysed in Triton X-100 buffer, and $\beta$-gal and luciferase assays were carried out using standard protocols (Ausubel et al. 1987). The measured relative light units (RLUs) were normalized to $\beta$-gal activity that served as an internal control for transfection efficiency. Figures 1, 2, 6, and 7 show the results of representative experiments in which individual data points were assayed in duplicate, and the mean and range of the results are shown. Each experiment was repeated two to five times. The degree of repression from a given site was highly consistent from experiment to experiment.

\section{Plasmid constructs for GST fusion proteins}

All GST fusion constructs were cloned into the BamHI site of the pGEX2T vector (Pharmacia). Cloning of N-CoR(1744-2453), N-CoR(1944-2453), N-CoR(1944-2239), N-CoR(2040-2239), and RevErb(200-614), RevErb(376-614), RevErb(376-601), and RevErb(419-614) have been described (Zamir et al. 1996). SMRT(9821495) and SMRT(1282-1495) were cloned using PCR with the $3^{\prime}$ primer, $5^{\prime}$-cgcggatccetcgctgtcggagagtgtct $-3^{\prime}$, and two $5^{\prime}$ primers, $5^{\prime}$-ctcggatcccaccacgccagcceggaccc-3' and $5^{\prime}$-gggggatccaatatcagccagcctgggac-3', respectively. GST-RevErb[200-614(407-18A)] was constructed using two rounds of PCR to mutate to alanines all 12 amino acids from 407 to 418 . The first round of PCR used primer combinations $\mathrm{P} 1$ and $\mathrm{P} 2$ and $\mathrm{P} 3$ and $\mathrm{P} 4$. The two PCR products were mixed and a second round of PCR using primers $\mathrm{P} 1$ and $\mathrm{P} 4$ followed. The primers are P1, 5' -gacggatccegagacgctgtgcgttttgg-3'; P2, 5'-gtacatgttcataggagctgccgccgcagcagccgctgcggcggccgccgcgggactgttggcaggtgcc-3'; P3，5'-aggcacctgccaacagtcccgcggcggccgccgcagcggctgctgcggcggcagctcctatgaacatgtacccgca-3'; P4, 5' -ccgggatccgccggccgggegggtcactg-3'. GST-RevErb(200-376) utilized the $5^{\prime}$ primer $\mathrm{Pl}$ and the $3^{\prime}$ primer, $5^{\prime}$-ccgggatcctcagctgtggtgtgcagggccag-3'. GST-RevErb(602-614) was made by annealing the following pair of oligonucleotides, kinasing the double-stranded oligonucleotide with T4-polynucleotide kinase, followed by ligation into the BamHI site of PGEX2T, $5^{\prime}$ gatccattccgagaagctgctgtccttccgggtggacgcccagtgac- $3^{\prime}$ and $5^{\prime}$ gatcgtcactgggagtccacccggaaggacagcagcttctcggaatgg- $3^{\prime}$. GST-RevErb(200-601) was made by cutting out the last $150 \mathrm{bp}$ of the GST-RevErb|376-601) construct using the restriction enzyme EcoRI and ligating this fragment into the GST-RevErb(200-614) construct digested previously with EcoRI at the same site. All PCR products, mutations, and fusion junctions were confirmed by sequencing.

\section{Plasmids for in vitro transcription/translation}

Full-length RevErb (Harding and Lazar 1995), RevErb DBD(103225) (Harding and Lazar 1995), full-length SMRT (Chen and Evans 1995), N-CoR(1510-2453) (Zamir et al. 1996), CMX-TR $\alpha 1$ (Reginato et al. 1996), pBS-RXR $\alpha$ (Reginato et al. 1996), CMXPPAR 1 (Kliewer et al. 1994), pSPORT-PPAR $\gamma 2$ (Tontonoz et al. 1994a), and pSPORT-PPAR $\gamma 2 \Delta \mathrm{AF} 2$ (above) were described elsewhere. TR $\beta 1$ was subcloned into the CMX-HA vector (Zamir et al. 1996). The constructs were transcribed using T7 RNA polymerase (except RXR $\alpha$, which requires T3 RNA polymerase) and translated in reticulocyte lysate (Promega) in the presence of $\left[{ }^{35} \mathrm{~S}\right]$ methionine for GST pulldown assays or in the presence of cold amino acids for use in electrophoretic mobility shift assays (EMSAs).

Protein-binding assays using GST fusion proteins

GST fusion proteins were expressed in BL21 bacteria by induc- 
tion with $0.5 \mathrm{~mm}$ IPTG at $30^{\circ} \mathrm{C}$. Proteins were isolated by cell lysis with lysozyme and detergent followed by sonication. GST beads $(50 \mu l)$ containing the fusion protein were incubated at room temperature in buffer $\mathrm{H}$, which consists of $50 \mathrm{mM} \mathrm{KCl}, 20$ mM HEPES (pH 7.9), 2 mM EDTA, 0.1\% NP-40, 10\% glycerol, $0.5 \%$ nonfat dry milk, and $5 \mathrm{mM}$ DTT. Five microliters of in vitro-translated N-CoR(1510-2453), SMRT, TR $\alpha 1$, TR $\beta 1$, $\operatorname{RXR} \alpha, \operatorname{RevErb}, \operatorname{PPAR} \gamma 1, \operatorname{PPAR} \gamma 2$, or PPAR $\gamma 2 \Delta \mathrm{AF} 2$ was added to the beads (input was $1 \mu \mathrm{l}$ ). Binding was allowed to proceed for $1 \mathrm{hr}$, and the beads were washed four times in the same buffer. The bound proteins were eluted by boiling in $30 \mu \mathrm{l}$ of SDSPAGE loading buffer and resolved by electrophoresis. The GST fusion proteins were stained with Coomassie blue to ensure equal loading, and the bound proteins were visualized by autoradiography.

\section{Preparing purified GST proteins for EMSA}

After sonication, 1\% Triton X-100 was added to bacterial extracts expressing GST-N-CoR(1944-2239), GST-N-CoR(17442453 ), or GST-SMRT(982-1495) fusion protein. Supernatants were purified on a glutathione-Sepharose column, washed five times with Tris-EDTA-NaCl in the presence of protease inhibitors $11 \mu \mathrm{g} / \mathrm{ml}$ of leupeptin, aprotinin, and pepstatin; $0.1 \mathrm{~mm}$ PMSF), and eluted with $20 \mathrm{~mm}$ reduced glutathione in $10 \%$ glycerol. Proteins were concentrated on a Millipore ultrafree-15 centrifugal filter device and dialyzed overnight against $1 \times$ DNA binding buffer. GST-N-CoR(1944-2239) was used for EMSA studies except in the experiment shown in Figure 3, where GST-N-CoR(1744-2453) was used.

\section{EMSA}

The top strand of the DNA probes used for EMSA include those oligonucleotides described for use in reporter constructs for transfection (RevDR2, Rev monomer, Rev monomer $\times 2$, and acyl CoA oxidase PPRE), as well as DR4(oct/oct), 5'-gatcctaaggtcaaataaggtcagagg-3', and TR(mono), 5' -gatcctaaggtcagatacttgtcggacg- $3^{\prime}$. These oligonucleotides were annealed with complementary bottom oligonucleotides thereby generating overhanging $\mathrm{BamHI}$ ends filled in with Klenow in the presence of $\left[{ }^{32} \mathrm{P}\right] \mathrm{dCTP}$. In vitro-translated receptors $(3-4 \mu \mathrm{l})$ were mixed with $15 \mu \mathrm{g}$ (unless otherwise indicated in the figure legend) of the specified corepressor protein purified from bacteria as a GST fusion. The proteins were preincubated at room temperature for $15 \mathrm{~min}$ in the standard $30-\mu \mathrm{l}$ binding reaction containing $1 \times$ binding buffer $(10 \mathrm{~mm}$ HEPES at $\mathrm{pH} 7.9,80 \mathrm{~mm} \mathrm{KCl}, 5 \%$ glycerol, $0.01 \mathrm{M}$ DTT), $200 \mu \mathrm{g} / \mu \mathrm{l}$ poly[d(I-C)], and $25 \mathrm{ng} / \mathrm{ml}$ of salmon sperm DNA. Labeled probe $(100,000 \mathrm{cpm})$ was added, and after incubation for $10 \mathrm{~min}$ at room temperature, reaction mixtures were loaded on a $5 \%$ polyacrylamide gel and separated in $0.5 \times$ Tris-borate-EDTA at room temperature. For supershift experiments, $\mathrm{RXR} \alpha$ antibody was used as described previously (Berrodin et al. 1992). Gels were dried prior to autoradiography.

\section{Acknowledgments}

We thank H. Harding for reagents and helpful discussions, C.B. Kallen for critical reading of the manuscript, and $M$. Reginato and $X$. Cheng for PPRE-luciferase reporter and TR $\beta$ expression plasmids, respectively. We are grateful to M.G. Rosenfeld and R.M. Evans for full-length N-CoR and SMRT expression plasmids, respectively. This work was supported by National Institutes of Health grants DK45586 and DK43806 (M.A.L.). I.Z. was supported by the Medical Scientist Training Program at the University of Pennsylvania (5P32GM07170).

The publication costs of this article were defrayed in part by payment of page charges. This article must therefore be hereby marked "advertisement" in accordance with 18 USC section 1734 solely to indicate this fact.

\section{References}

Adelmant, G., A. Begue, D. Stehelin, and V. Laudet. 1996. A functional Rev-erb $\alpha$ responsive element located in the human Rev-erb $\alpha$ promoter mediates a repressive function. Proc. Nat1. Acad. Sci. 93: 3553-3558.

Ausubel, F.M., R. Brent, R. Kingston, D.D. Moore, J.A. Smith, J.G. Seidman, and K. Struhl. 1987. Current protocols in molecular biology. Wiley Interscience/Greene Publishing, New York, NY.

Baniahmad, A., A.C. Kohne, and R. Renkawitz. 1992. A transferable silencing domain is present in the thyroid hormone receptor, in the v-erbA oncogene product and in the retinoic acid receptor. EMBO I. 11: 1015-1023.

Baniahmad, A., X. Leng, T.P. Burris, S.Y. Tsai, M.-J. Tsai, and B.W. O'Malley. 1995. The $\tau 4$ activation domain of the thyroid hormone receptor is required for release of a putative corepressor(s) necessary for transcriptional silencing. Mol. Cell. Biol. 15: 76-86.

Barettino, D., M.d.M. Vivanco-Ruiz, and H.G. Stunnenberg. 1994. Characterization of the ligand-dependent transactivation domain of thyroid hormone receptor. EMBO $J$. 13: 3039-3049.

Berrodin, T.J., M.S. Marks, K. Ozato, E. Linney, and M.A. Lazar. 1992. Heterodimerization among thyroid hormone receptor, retinoic acid receptor, retinoid $\mathrm{X}$ receptor, chicken ovalbumin upstream promoter transcription factor, and an endogenous nuclear protein. Mol. Endocrinol. 6: 1468-1478.

Brent, G.A., M.K. Dunn, J.W. Harney, T. Gulick, P.R. Larsen, and D.D. Moore. 1989. Thyroid hormone aporeceptor represses T3-inducible promoters and blocks activity of the retinoic acid receptor. New Biol. 1: 329-336.

Casanova, J., E. Helmer, S. Selmi-Ruby, J.S. Qi, M. Au-Fliegner, V. Desai-Yajnik, N. Koudinova, F. Yarm, B.M. Raaka, and H.H. Samuels. 1994. Functional evidence for ligand-dependent dissociation of thyroid hormone and retinoic acid receptors from an inhibitory cellular factor. Mol. Cell. Biol. 14: $5756-5765$.

Cavailles, V., S. Dauvois, F. L'Horset, G. Lopez, S. Hoare, P.J. Kushner, and M.G. Parker. 1995. Nuclear factor RIP140 modulates transcriptional activation by the estrogen receptor. EMBO I. 14: 3741-3751.

Chakravarti, D., V.J. LaMorte, N.C. Nelson, T. Nakajima, I.G. Schulman, H. Juguilon, M. Montminy, and R.M. Evans. 1996. Role of CBP/p300 in nuclear receptor signaling. $\mathrm{Na}$ ture 383: 99-103.

Chawla, A. and M.A. Lazar. 1993. Induction of Rev-ErbAc, an orphan nuclear receptor encoded on the opposite strand of the $\alpha$-thyroid hormone receptor gene, during adipocyte differentiation. J. Biol. Chem. 268: 16265-16269.

Chawla, A., E.J. Schwarz, D.D. Dimaculangan, and M.A. Lazar. 1994. Peroxisome proliferator-activated receptor $\gamma$ (PPAR $\gamma$ ): Adipose predominant expression and induction early in adipocyte differentiation. Endocrinology 135: 798-800.

Chen, J.D. and R.M. Evans. 1995. A transcriptional co-repressor that interacts with nuclear hormone receptors. Nature 377: 454-457.

Chen, J.-Y., S. Penco, J. Ostrowski, P. Balaguer, M. Pons, J.E. 
Starrett, P. Reczek, P. Chambon, and H. Gronmeyer. 1995. RAR-specific agonist/antagonists which dissociate transactivation and AP1 transrepression inhibit anchorage-independent cell proliferation. EMBO I. 14: 1187-1197.

Chen, J.D., K. Umesono, and R.M. Evans. 1996. SMRT isoforms mediate repression and anti-repression of nuclear receptor heterodimers. Proc. Natl. Acad. Sci. 93: 7567-7571.

Damm, K., C.C. Thompson, and R.M. Evans. 1989. Protein encoded by v-erbA functions as a thyroid-hormone receptor antagonist. Nature 339: 593-597.

Danielian, P.S., R. White, J.A. Lees, and M.G. Parker. 1992. Identification of a conserved region required for hormone dependent transcriptional activation by steroid hormone receptors. EMBO I. 11: 1025-1033.

Darling, D.S., R.L. Carter, P.M. Yen, J.M. Welborn, W.W. Chin, and P.K. Umeda. 1993. Different dimerization activities of alpha and beta thyroid hormone receptor isoforms. I. Biol. Chem. 268: 10221-10227.

Devchand, P.R., H. Keller, J.M. Peters, M. Vazquez, F.J. Gonzalez, and W. Wahli. 1996. The PPAR $\alpha$-leukotrience B4 pathway to inflammation control. Nature 384: 39-43.

Downes, M., A.J. Carozzi, and G.E.O. Muscat. 1995. Constitutive expression of the orphan receptor, Rev-ErbA $\alpha$, inhibits muscle differentiation and abrogates the expression of the myoD gene family. Mol. Endocrinol. 9: 1666-1678.

Dreyer, C., G. Krey, H. Keller, F. Givel, G. Helftenbein, and W. Wahli. 1992. Control of the peroxisomal $\beta$-oxidation pathway by a novel family of nuclear hormone receptors. Cell 68: 879-887.

Durand, B., M. Saunders, C. Gaudon, B. Roy, R. Losson, and P. Chambon. 1994. Activation function 2 (AF-2) of retinoic acid receptor and 9-cis retinoic acid receptor: Presence of a conserved autonomous constitutive activating domain and influence of the nature of the response element on AF-2 activity. $E M B O$ J. 13: 5370-5382.

Fondell, J.D., A.L. Roy, and R.G. Roeder. 1993. Unliganded thyroid hormone receptor inhibits formation of a functional preinitiation complex: Implications for active repression. Genes \& Dev. 7: 1400-1410.

Forman, B.M., J. Chen, B. Blumberg, S.A. Kliewer, R. Henshaw, E.S. Ong, and R.M. Evans. 1994. Cross-talk among ROR $\alpha 1$ and the Rev-erb family of orphan nuclear receptors. Mol. Endocrinol. 8: 1253-1261.

Graupner, G., K.N. Wills, M. Tzukerman, X.-K. Zhang, and M. Pfahl. 1989. Dual regulatory role for thyroid-hormone receptors allows control of retinoic-acid receptor activity. Nature 340: 653-656.

Halachmi, S., E. Marden, G. Martin, H. MacKay, C. Abbondanza, and M. Brown. 1994. Estrogen receptor-associated proteins: Possible mediators of hormone-induced transcription. Science 264: 1455-1458.

Hanstein, B., R. Eckner, J. DiRenzo, S. Halachmi, H. Liu, B. Searcy, R. Kurokawa, and M. Brown. 1996. P300 is a component of an estrogen receptor coactivator complex. Proc. Natl. Acad. Sci. 93: 11540-11545.

Harding, H.P. and M.A. Lazar. 1993. The orphan receptor RevErbA $\alpha$ activates transcription via a novel response element. Mol. Cell. Biol. 13: 3113-3121.

- 1995. The monomer-binding orphan receptor Rev-Erb represses transcription as a dimer on a novel direct repeat. Mol. Cell. Biol. 15: 4791-4802.

Horlein, A.J., A.M. Naar, T. Heinzel, J. Torchia, B. Gloss, R. Kurokawa, A. Ryan, Y. Kamei, M. Soderstrom, C.K. Glass, and M.G. Rosenfeld. 1995. Ligand-independent repression by the thyroid hormone receptor mediated by a nuclear receptor co-repressor. Nature 377: 397-404.
Kamei, Y., L. Xu, T. Heinzel, J. Torchia, R. Kurokawa, B. Gloss, S.-C. Lin, R.A. Heyman, D.W. Rose, C.K. Glass, and M.G. Rosenfeld. 1996. A CBP integrator complex mediates transcriptional activation and AP-1 inhibition by nuclear receptors. Cell 85: 403-414.

Katz, R.W. and R.J. Koenig. 1993. Nonbiased identification of DNA sequences that bind thyroid hormone receptor alpha 1 with high affinity. J. Biol. Chem. 268: 19392-19397.

- 1994. Specificity and mechanism of thyroid hormone induction from an octamer response element. 7 . Biol. Chem. 269: 18915-18920.

Keller, H., C. Dreyer, J. Medin, A. Mahfoudi, K. Ozato, and W. Wahli. 1993. Fatty acids and retinoids control lipid metabolism through activation of peroxisome proliferator activated receptor-retinoid X receptor heterodimers. Proc. Natl. Acad. Sci. 90: 2160-2164.

Kliewer, S.A., B.M. Forman, B. Blumberg, E.S. Ong, U. Borgmeyer, D.J. Mangelsdorf, K. Umesono, and R.M. Evans. 1994. Differential expression and activation of a family of murine peroxisome proliferator-activated receptors. Proc. Nat1. Acad. Sci. 91: 7355-7359.

Kurokawa, R., M. Soderstrom, A. Horlein, S. Halachmi, M. Brown, M.G. Rosenfeld, and C.K. Glass. 1995. Polarity-specific activities of retinoic acid receptors determined by a co-repressor. Nature 377: 451-454.

Lazar, M.A. 1993. Thyroid hormone receptors: Multiple forms, multiple possibilities. Endocr. Rev. 14: 184-193.

Lazar, M.A. and T.J. Berrodin. 1990. Thyroid hormone receptors form distinct nuclear proteins-dependent and independent complexes with a thyroid hormone response element. Mol. Endocrinol. 4: 1627-1635.

Lazar, M.A., R.A. Hodin, D.S. Darling, and W.W. Chin. 1989. A novel member of the thyroid/steroid hormone receptor family is encoded by the opposite strand of the rat c-erbA $\alpha$ transcriptional unit. Mol. Cell. Biol. 9: 1128-1136.

Lazar, M.A., T.J. Berrodin, and H.P. Harding. 1991. Differential DNA binding by monomeric, homodimeric, and potentially heteromeric forms of the thyroid hormone receptor. Mol. Cell. Biol. 11: 5005-5015.

LeDouarin, B., C. Zechel, J.-M. Garnier, Y. Lutz, L. Tora, B. Pierrat, D. Heery, H. Gronemeyer, P. Chambon, and R. Losson. 1995. The $\mathrm{N}$-terminal part of TIF1, a putative mediator of the ligand-dependent activation function (AF-2) of nuclear receptors, is fused to B-raf in the oncogenic protein $\mathrm{T} 18$. EMBO T. 14: 2020-2033.

Lee, J.W., F. Ryan, J.C. Swaffield, S.A. Johnston, and D.D. Moore. 1995. Interaction of thyroid-hormone receptor with a conserved transcriptional mediator. Nature 374: 91-94.

Maia, A.L., J.W. Harney, and P.R. Larsen. 1996. Is there a negative TRE in the luciferase reporter cDNA? Thyroid 6: 325328

Martin, B., R. Renkawitz, and M. Muller. 1994. Two silencing sub-domains of v-erbA synergize with each other, but not with RXR. Nucleic Acids Res. 22: 4899-4905.

Minucci, S., D.J. Zand, A. Dey, M.S. Marks, T. Nagata, J.F. Grippo, and K. Ozato. 1994. Dominant negative retinoid X receptor $\beta$ inhibits retinoic acid-responsive gene regulation in embryonal carcinoma cells. Mol. Cell. Biol. 14: 360-372.

Miyajima, N., R. Horiuchi, Y. Shibuya, S. Fukushige, K. Matsubara, K. Toyoshima, and T. Yamamoto. 1989. Two erbA homologs encoding proteins with different $\mathrm{T} 3$ binding capacities are transcribed from opposite DNA strands of the same genetic locus. Cell 57: 31-39.

Onate, S.A., S.Y. Tsai, M.-J. Tsai, and B.W. O'Malley. 1995. Sequence and characterization of a coactivator for the steroid hormone receptor superfamily. Science 270: 1354-1357. 
Piedrafita, F.J., I. Bendik, M.A. Ortiz, and M. Pfahl. 1995. Thyroid hormone receptor homodimers can function as ligandsensitive repressors. Mol. Endocrinol. 9: 563-578.

Reginato, M.J., J. Zhang, and M.A. Lazar. 1996. DNA-independent and DNA-dependent mechanisms regulate the differential heterodimerization of the isoforms of the thyroid hormone receptor with retinoid X receptor. I. Biol. Chem. 271: 28199-28205.

Retnakaran, R., G. Flock, and V. Giguere. 1994. Identification of RVR, a novel orphan nuclear receptor that acts as a negative transcriptional regulator. Mol. Endocrinol. 8: 1234-1244.

Sande, S. and M.L. Privalsky. 1996. Identification of TRACs, a family of co-factors that associate with and modulate the activity of nuclear hormone receptors. Mol. Endocrinol. 10: $813-825$.

Sap, J., A. Munoz, K. Damm, Y. Goldberg, J. Ghysdael, A. Lentz, H. Beug, and B. Vennstrom. 1986. The c-erbA protein is a high affinity receptor for thyroid hormone. Nature 324: 635640.

Sap, J., A. Munoz, J. Schmitt, H. Stunnenberg, and B. Vennstrom. 1989. Repression of transcription mediated at a thyroid hormone response element by the v-erbA oncogene product. Nature 340: 242-244.

Schulman, I.G., H. Juguilon, and R.M. Evans. 1996. Activation and repression by nuclear hormone receptors: Hormone modulates an equilibrium between active and repressive states. Mo1. Cell. Biol. 16: 3807-3813.

Seol, W., M.J. Mahon, Y.-K. Lee, and D.D. Moore. 1996. Two receptor interacting domains in the nuclear hormone receptor corepressor RIP13/N-CoR. Mol. Endocrinol. 10: 16461655 .

Tillman, J.B., D.E. Crone, H.-S. Kim, C.N. Sprung, and S.R. Spindler. 1993. Promoter independent down-regulation of the firefly luciferase gene by $\mathrm{T} 3$ and $\mathrm{T} 3$ receptor in CV-1 cells. Mol. Cell. Endocrinol. 95: 101-109.

Tontonoz, P., E. Hu, R.A. Graves, A.I. Budavari, and B.M. Spiegelman. 1994a. mPPAR $\gamma 2$ : Tissue-specific regulator of an adipocyte enhancer. Genes \& Dev. 8: 1224-1234.

Tontonoz, P., E. Hu, and B.M. Spiegelman. 1994b. Stimulation of adipogenesis in fibroblasts by PPAR $\gamma 2$, a lipid-activated transcription factor. Cell 79: 1147-1156.

Tontonoz, P., E. Hu, J. Devine, E.G. Beale, and B.M. Spiegelman. 1995. PPAR $\gamma 2$ regulates adipose expression of the phosphoenolpyruvate carboxykinase gene. Mol. Cell. Biol. 15: 351357.

Xue, J.-C., E.J. Schwarz, A. Chawla, and M.A. Lazar. 1996. Distinct stages in adipogenesis revealed by retinoid inhibition of differentiation after induction of PPARy. Mol. Cell. Biol. 16: $1567-1575$.

Yu, K., W. Bayona, C.B. Kallen, H.P. Harding, C. Ravera, J. McMahon, M. Brown, and M.A. Lazar. 1995. Differential activation of peroxisome proliferator-activated receptors by eicosanoids. J. Biol. Chem. 270: 23975-23983.

Zamir, I., H.P. Harding, G.B. Atkins, A. Horlein, C.K. Glass, M.G. Rosenfeld, and M.A. Lazar. 1996. A nuclear hormone receptor corepressor mediates transcriptional silencing by receptors with different repression domains. Mol. Cell. Biol. 16: $5458-5465$. 


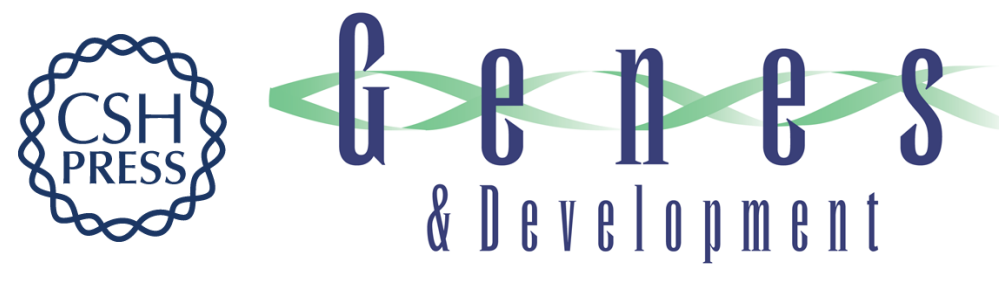

\section{Stoichiometric and steric principles governing repression by nuclear hormone receptors.}

I Zamir, J Zhang and M A Lazar

Genes Dev. 1997, 11:

Access the most recent version at doi:10.1101/gad.11.7.835

References This article cites 61 articles, 26 of which can be accessed free at: http://genesdev.cshlp.org/content/11/7/835.full.html\#ref-list-1

License

Email Alerting

Service

Receive free email alerts when new articles cite this article - sign up in the box at the top right corner of the article or click here.

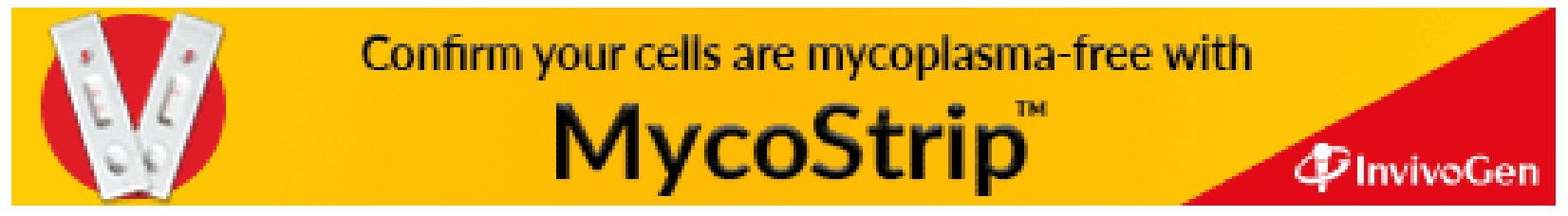

